\title{
Аналіз енергетичних показників конденсаторів холодильних установок з повітряним охолодженням
}

\section{П. Ф. Стоянов}

Одеська національна академія харчових технологій, вул. Канатна, 112, Одеса, 65039, Україна

$\triangle$ e-mail: palfomich@gmail.com

\begin{abstract}
В статті виконано літературний огляд досліджень пов'язаних з удосконаленням теплообмінників з повітряним охолодженням, аналіз енергетичних показників конденсаторів з повітряним охолодженням, представлені основні напрямки підвищення їх енергетичної ефективності. Автором статті досліджено роботу повітряного конденсатора при зміні режимних параметрів його експлуатації, оцінено вплив робочого тіла холодильноі установки на характеристики теплообмінника. Результати проведеного дослідження свідчать, щьо робоче тіло холодильної установки істотно впливає (до 9,2\%) на показники теплової потужності обладнання в рівноцінних умовах експлуатаџіï. Оцінено залежність витрати охолоджуючого повітря крізь теплообмінник, зміни необхідної потужності вентилятора від температури охолоджуючого повітря на вході в апарат за умови дотримання фіксованої температури конденсації хладону та теплової потужності конденсатору. Виявлено, щзо при підвищенні температурі зовнішнього повітря від $25^{\circ} \mathrm{C}$ до $28{ }^{\circ} \mathrm{C}$ відбувається підвищення енергоспоживання вентилятора серійного апарату на 250\%. В роботі очінено енергетичну ефективність конденсаторів повітряного охолодження в залежності від параметрів навколишнього середовища, сформовані рекомендаціi щзодо оптимізації роботи теплообмінників з повітряним охолодженням.
\end{abstract}

Ключові слова: моделювання; повітряний конденсатор; енергетична ефективність; теплообмін; щъільність теплового потоку; холодильний агент; оптимізація.

\section{1. Вступ}

Конденсатори холодильних установок з повітряним охолодженням широко використовуються в промисловості. Це пов'язано з високими енергетичними показниками апаратів даного типу та легкістю їх технічного обслуговування. Повітряні конденсатори торгівельного холодильного обладнання при зміні холодовидатності в межах 10-15 кВт змінюють свої габаритні розміри приблизно у тій же мірі, як і компресор. Однак, при збільшенні холодовидатності установки розміри конденсатора збільшуються значно швидше, аніж компресорів [1]. Це призводить до необхідності передбачення окремого конденсаторного відділення, яке улаштовується, наприклад, на даху торгівельних приміщень. Повітряні конденсатори є доволі металоємними апаратами та займають багато місця, тому подальше поліпшення енергетичних та масогабаритних характеристик апаратів з повітряним охолодженням $є$ пріоритетною та актуальною задачею.

Аналіз літературних джерел [2,3] підтверджує великий потенціал енергозбереження при оптимальній експлуатації конденсаторів 3 повітряним охолодженням. При цьому аргументовано доведено, що оптима- льний режим роботи теплообмінника обумовлено комбінацією багатьох режимних параметрів. Суттєвий вплив на енергоефективну роботу апаратів 3 повітряним охолодженням здійснює швидкість прокачування повітря крізь апарат, конфігурація теплообмінної поверхні та оребрених теплообмінних елементів. Результати раніше проведених досліджень свідчать, що економія енергоресурсів може сягати від 5 до 50\% лише за допомогою підбору оптимальної швидкості повітря [4].

Холодильні установки малої потужності 3 конденсаторами повітряного охолодження (КПО) поширені в малому торговому обладнанні, побутових холодильних апаратах і кондиціонерах. Тепловіддача в них здійснюється дуже ефективно внаслідок примусової подачі великої кількості повітря за допомогою осьового або відцентрового вентилятора через конденсатор холодильного агрегату, за винятком дуже малих побутових апаратів, які охолоджуються при природній циркуляції повітря. Конденсатори повітряного охолодження для малих холодильних установок легко монтуються, недорогі в обслуговуванні, надійно працюють при низькій зовнішній температурі повітря. Однак для їх роботи необхідно досить велика кількість повітря, при цьому робота вентилятора створює шумовий ефект. У зонах 3 дуже жарким кліматом тиск конденсації може підняти- 
ся вище нормального через відносно високу температуру навколишнього середовища. У випадку, коли є необхідна площа поверхні теплообміну, КПО нормально експлуатуються у всіх кліматичних зонах.

Значне скорочення витрат електроенергії і води, яка охолоджує холодильний агент у теплообміннику, може бути забезпечено за рахунок широкого впровадження на підприємствах різних галузей промисловості холодильних установок з КПО. Досвід застосування схем таких установок на ряді підприємств хімічної, птахопереробної, газової та інших галузей промисловості доводить їх ефективність, особливо в районах 3 помірним і холодним кліматом. Перспективні вони також для підприємств м'ясної і молочної промисловості.

Тематика даної роботи пов'язана 3 дослідженням енергетичних характеристик серійних теплообмінних апаратів 3 повітряним охолодженням, виявлення основних факторів, які впливають на масогабаритні та теплоаеродинамічні характеристики. Основна мета даної роботі полягає в аналізі існуючих конструкцій конденсаторів з повітряним охолодженням, дослідженні впливу типу хладогенту на технічні та енергетичні характеристики теплообмінників, виявлення можливих шляхів підвищення їх енергетичної ефективності.

\section{2. Вплив конструктивних та режимних параме- трів на характеристики конденсаторів 3 пові- тряним охолодженням}

Теплоенергетичні характеристики конденсаторів 3 повітряним охолодженням залежать від різноманітних параметрів, таких як: геометричні характеристики поверхні теплообміну (діаметр теплообмінних труб, крок оребрення, коефіцієнт оребрення та т.п.), теплофізичних властивостей робочого тіла холодильної установки, конструктивних матеріалів теплообмінника та обраної технології виготовлення конденсатору (його окремих елементів), параметрів охолоджуючого середовища.

Робота [5] присвячена дослідженню питання впливу матеріалу теплообмінних труб на ефективність конденсаторів 3 повітряним охолодженням у складі водоохолоджуючих машин (чилерів). Проаналізовано наслідки зміни мідних труб на алюмінієві. Алюміній корозійно стійкий матеріал та добре піддається механічній обробці. Дослідження проведено на базі холодильної установки заправленої холодильним агентом R134a. Авторами роботи підкреслено, що ефективність роботи теплообмінника суттєво залежить від довжини теплообмінної поверхні, яка омивається потоком повітря, типу оребрення, шорсткості поверхні теплообміну, швидкостей середовища (повітря), параметрів холодильного агенту на вході та виході $з$ конденсатору. На економічні показники теплообмінника суттєвий вплив також здійснює собівартість матеріалу труб. У випадку використання алюмінію цей показник покращується.

Різні дослідники у своїх роботах робили індивідуальні рекомендації щодо удосконалення роботи теплообмінних апаратів з повітряним охолодженням при роботі на R134a. Дослідник Hassab з колегами у роботі [6] представили модель конденсатору з повітряним охоло- дженням в стаціонарних умовах експлуатації з розробленими рекомендаціями та математичними рівняннями по розрахунку теплових та аеродинамічних характеристик апарату.

У роботі [7] досліджено вплив наслідків зварювання алюмінієвих теплообмінників на роботу холодильної установки, заправленої R407C та поліефірним мастилом. Виявлено, що присутність флюсу після зварювання теплообмінників призводить до негативного впливу на умови роботи апаратів та стабільність холодильних систем. Особливо це відчутно при несприятливих умовах таких як, відсутність фільтра-осушувача в холодильному контурі або у випадку підвищеного вологовмісту фільтруючого елементу. Результати досліджень роботи [7] свідчать, що використання алюмінієвих труб в теплообмінниках 3 повітряним охолодженням призводить до здешевлення виробництва. Основний термічний опір зосереджено з боку повітря, тому заміна мідних трубок на алюмінієві практично не впливає на загальний коефіцієнт теплопередачі апарату. Перехід на алюмінієві труби дозволяє зменшити вагу апарату та його ціну, негативний вплив на навколишнє середовище, спростити процес переробки теплообмінника та згодом його утилізації. 3 економічної точки зору перехід на алюмінієві труби теплообмінника дозволяє підвищити техніко-економічні показники апарату прибли3 но на $24 \%$.

У роботі [8] автори оптимізували теплообмінники шляхом удосконалення геометрії для мінімізації об'ємно-масових характеристик та зменшення аеродинамічного опору апарату, швидкостей повітря. Було вивчено вплив на теплообмін та об'ємно-масові характеристики кроку оребрення та діаметру теплообмінних труб. Авторами роботи [8] представлено програму для розрахунку повітряного теплообмінника 3 можливістю зміни геометрії оребрення, швидкості повітря та параметрів холодильного агенту на вході в апарат. При фіксованій глибині теплообмінної секції та кроці оребрення оптимізувалися діаметр труби та крок ребер відповідно до площі поперечного перерізу та масової швидкості потоку повітря. При цьому перепад тиску не приймався постійним. Вищезазначене зроблене для дотримання балансу між витратами на прокачування повітря крізь теплообмінник та загальними витратами. Максимальна швидкість потоку складала 3 м/с 3 метою виключення проблем виносу крапель вологи з поверхні теплообміну.

Conklu у статті [9] представили програму розрахунку теплообмінника для компанії Ford Motor Company для визначення ефективності автомобільних конденсаторів. Коефіцієнти тепловіддачі з боку повітря та холодильного агенту визначаються на базі емпіричних рівнянь. Програма розраховує швидкість відводу теплоти для визначених геометрії ядра, температури конденсації, температури та швидкості повітря на вході. Оптимізується конденсатор відповідно до обмежень (котрі обирають розробником обладнання) на ефективні параметри для швидкості відводу теплоти, температури конденсації та параметрів повітря на вході. Результати моделювання відрізняються від експериментальних даних у межах $3 \%$. 
Davis 3 колегами у роботі [10] на замовлення компанії Chrysler Corporation вивчали роботу повітряного конденсатору за результатами розрахунків в програмі комп'ютерного моделювання. Робота вентиляторів в програмі розрахунку не проаналізована. Програма розраховує потужність теплообмінника по заданим параметрам повітря на вході та виході повітря, геометрії теплообмінника та параметрам холодильного агенту. Також розраховується тепловий баланс між випарником та конденсатором установки. В роботі зауважено, що оптимізація потужності системи здійснюється у співвідношенні розрахункових навантажень та економічних врахувань. Авторами отримані результати моделювання, які добре узгоджуються 3 результатами натурних випробувань.

Schoonman в статті[11] запропонував економічну оптимізацію великої багатосекційної системи повітроохолоджувача для промислового застосування. Дослідження містить оптимізацію поверхні теплообміну та врахування капітальних, монтажних та експлуатаційних витрат. Результати підтверджують суттєву економію за результатами оптимізації роботи вентиляторів теплообмінника.

Рушійна сила охолодження пари в повітряному конденсаторі - різниця температур між пароподібним холодильним агентом та температурою навколишнього середовища. Одним з варіантів підвищення ефективності роботи повітряного охолодження виступає зрошення поверхні теплообміну дрібнодисперсно розпиленою водою. Наразі повітряні конденсатори даного типу виготовляються відомими світовими виробниками теплообмінних апаратів. Причому, слід зауважити, що теплообмінники 3 даним функціоналом $\epsilon$ ще доволі дорогі та можуть працювати обмежений період часу без додаткового технічного обслуговування.

Kutscher C. та Costenaro D. у роботі [12] розробили модель для оцінки вартості та продуктивності різних методів випарного охолодження для підвищення ефективності роботи конденсаторів 3 повітряним охолодженням. Системи, в яких вода безпосередньо контактує 3 теплообмінними трубками, мають найвищий рівень технічної та економічної привабливості. Проте експлуатація таких систем супроводжується підвищеною корозією та відкладенням на поверхні теплообміну вапняного нальоту.

SaizJabarrdo, J.M. та Mamani,W.G. у роботі [13] розробили імітаційну модель на основі поділу конденсатору на три зони (перегрівання, конденсація і переохолодження). Кожна зона теплообмінного апарату розглядається як незалежний теплообмінник, при цьому невідповідність між експериментальними даними та результатами моделювання мінімальна.

У роботі [20] запропоновано новий підхід оптимізації роботи повітряного конденсатору. Для цього використовується попереднє охолодження повітря, яке надходить в конденсатор у випадку коли температура за сухим термометром перевищує $20^{\circ} \mathrm{C}$. Запропонована процедура апробована на установці потужністю 171 МВт. Вона дозволила заощадити 2,5\% потужності (4,2 МВт) без використання будь-якої води для розпилення або витрат на попередню обробку води.

Робота Таррада та колег [14-16] була зосереджена на дослідженні показників теплопередачі та моделювання повітряного охолодження теплообмінників. Проведені дослідження показали, що теплова ефективність залежить від геометричних параметрів поверхні теплообміну та кількості і конфігурації рядів труб теплообмінника.

Таррад у роботі [17] розробив комп'ютерну модель для виконання прогнозу сухого охолодження конденсаторів $з$ повітряним охолодженням, які застосовуються на електростанціях. Програма враховувала зміну теплофізичних параметрів повітря в залежності від зміни температури повітря по глибині апарату. Результати роботи програми показали покращення роботи конденсатору до 23\% при попередньому охолодженні повітря. Температура повітря зменшувалася 345 до $28{ }^{\circ} \mathrm{C}$ при швидкості повітря від 3,6 м/с.

Таррад та Худор [18] представили досить прості рівняння та адаптовані для практичного використання на стороні повітря для розрахунку коефіцієнту теплопередачі у вигляді безрозмірних критеріїв. Рівняння враховує геометрію оребрення, кількість рядів та умови експлуатації теплообмінника. Дослідники зауважують, що похибка рівнянь становить для розрахунку теплового потоку та коефіцієнту теплопередачі теплообмінника відповідно $13 \%$ та $10 \%$.

Якобсоном В.Б. було встановлено [19], що зі збільшенням кількості рядів труб коефіцієнт теплопередачі конденсатора 3 повітряним охолодженням зменшується. В конденсаторах 3 великою кількістю секцій знижується витрата повітря, що викликає зростання температури повітря на виході з конденсатору, відповідно зростає середня температура повітря, а значить й температура конденсації холодильного агенту. Енергетичні показники таких конденсаторів нижчі, аніж конденсаторів з малою кількістю секцій (рядів труб по глибині апарату).

В повітряних конденсаторах низькотемпературних агрегатів іноді завищують площу конденсатора. Це дозволяє знизити температуру обмотки вбудованого електродвигуна та конденсації, а також необхідну потужність електродвигуна. Таке рішення виправдане, так як дещо завищена площа теплообміну окупається меншими експлуатаційними витратами на електроенергію.

У роботі [20] досліджено експериментально та теоретично питання підвищення ефективності роботи конденсатора $з$ повітряним охолодженням автомобільних кондиціонерів. Холодильна машина працювала на природньому холодильному агенті R290. Оптимізація роботи повітряного конденсатору проводилася шляхом варіювання геометричних параметрів поверхні теплообміну конденсатору, кількості рядів труб, зміни швидкості повітря. Експеримент було проведено при зміні еквівалентного діаметру каналу 4,2; 5,2; 7,2 та 9,52 мм. При варіюванні зовнішнього діаметру каналу коефіцієнт перетворення енергії холодильної машини змінюється. Однак, при цьому максимальне значення коефіцієнта перетворення енергії холодильної машини відповідало еквівалентному діаметру каналу 5,2 мм. При зміні кількості рядів труб та кроку ребер було виявлено, що при розміщення 12 ребер на 1 дюймі довжини труби та при двох рядах труб значення коефіцієнту перетворення енергії холодильної машини максимальне. Експериментальним шляхом було також підтверджено, що при збільшенні швидкості потоку повітря ефективність 
роботи конденсатору підвищується. При цьому максимальний приріст ефективності холодильної установки спостерігається при підвищенні швидкості потоку повітря $33 \mathrm{~m} / \mathrm{c}$ до $6 \mathrm{~m} / \mathrm{c}$. При швидкості повітря 7 та 8 м/с ефективність системи стає вже нижчою та відповідає випадку роботи системи при швидкості повітря $5 \mathrm{~m} / \mathrm{c}$. Отримані результати пов'язані з тим, що теплообмін 3 боку повітря при підвищенні швидкості повітря вище значення 6 м/с виходить на автомодельний режим. Подальше підвищення швидкості потоку повітря призводить лише до збільшення потрібної потужності вентилятора конденсатору при практично незмінному коефіцієнті тепловіддачі з боку повітря.

J.B. Copettiet у роботі [21] розробив та оптимізував мікроканальний конденсатор, заправлений холодильним агентом R134a. Оптимізація теплообмінника була реалізована зміною геометричних параметрів 3 боку холодильного агенту, кількості каналів та висоти каналу.

Представлені експериментальні та теоретичні дослідження роботи теплообмінників 3 повітряним охолодженням свідчать про багатогранність можливих шляхів підвищення енергоефективності апаратів даного типу.

\section{3. Моделювання роботи серійних конденсаторів 3 повітряним охолодженням}

Фірми-виробники теплообмінного обладнання надають у вільному доступі програми підбору серійного обладнання. Програми підбору обладнання дають змогу інженерам у короткі строки провести підбір теплообмінника, розрахувати експлуатаційні показники певної марки обладнання при зміні режимних параметрів експлуатації. Функціонал програм дозволяє доволі швидко підібрати необхідну лінійку повітряних теплообмінників різного конструктивного виконання.

Метою розрахунків у програмі GPC.EU Customer був аналіз режимних та конструктивних характеристик серійних повітряних конденсаторів. Для формування виборки теплообмінного обладнання було прийнято наступні вихідні дані:

- температура конденсації холодильного агенту $45^{\circ} \mathrm{C}$;

- необхідна потужність апарату - 30 кВт;

- температура зовнішнього повітря - $32{ }^{\circ} \mathrm{C}$;

- відносна вологість повітря - $60 \%$.

При виборі типів холодильного агенту, якими буде заправлено холодильну установку, було враховано сучасні тенденції в сфері застосування робочих тіл холодильних установок та діючі законотворчі документи. В якості робочих тіл холодильної установки було прийнято наступні хладони: R1270, R290, R404a, R507a та R417a.

За результатами роботи в програмному комплексі було проаналізовано вплив холодильного агенту холодильної установки на питомі показники конденсатору 3 повітряним охолодженням.

На рисунку 1 представлено графік зміни глибини переохолодження холодильного агенту в серійних конденсаторах в залежності від питомої витрати повітря крізь апарат. Підвищення глибини переохолодження холодильного агенту у конденсаторі при збільшенні питомої витрати повітря пов'язане 3 більш високими швидкостями повітря в живому перетині теплообмінника, підвищенням інтенсивності теплозйому. Підвищення глибини переохолодження холодильного агенту на виході 3 конденсатору пов'язано зі зменшенням середньої температури охолоджуючого повітря та підвищенням у зв'язку з цим температурного напору в апараті.

При роботі холодильної установки зниження температури холодоагенту після конденсатору на один градус відповідає підвищенню потужності холодильної машини приблизно на 1\% при тому ж рівні енергоспоживання. Найбільший рівень переохолодження відповідає варіанту заправки холодильної установки хладоном R404a, найнижчий - R290 та R1270.

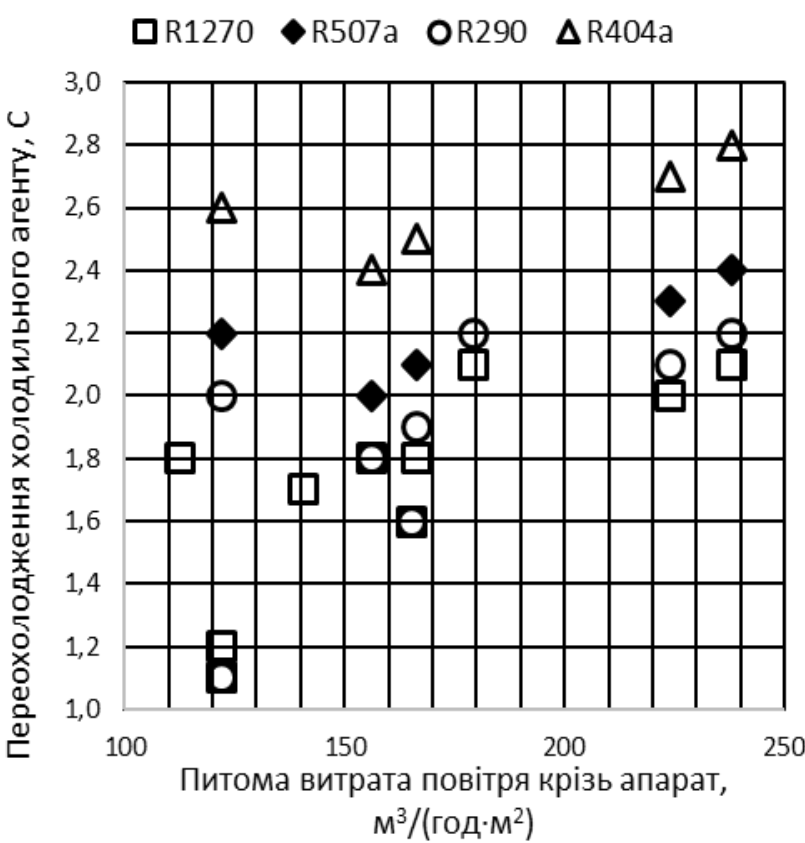

Рисунок 1 - Графік зміни глибини переохолодження холодильного агенту у конденсаторі в залежності від питомої витрати повітря крізь апарат

На рисунку 2 представлено графік зміни витрати холодильного агенту в залежності від потужності теплообмінника та заправленого холодильного агенту. Вихідні дані для аналізу взято для виборки однотипних серійних конденсаторів фірми Guntner марки GCHC RD 050. Найбільша об'ємна витрата холодильного агенту крізь теплообмінник при фіксованій температурі конденсації відповідає варіанту використання хладону R290 та R1270, об’ємна витрата холодильного агенту для R404a тa R507a практично рівноцінні та мінімальні. При цьому об'ємна витрата холодильного агенту крізь апарат працюючий на R290 буде на 52\% вище об'ємної витрати крізь апарат на R507a. Це пояснюється різницею густин парів холодильних агентів. Швидкість парів холодильного агенту в нагнітальному трубопроводі холодильної установки згідно з рекомендаціями підтримується на рівні 10-18 м/с. При збільшенні об'ємної витрати крізь апарат згідно з рівнянням нерозривності потоку збільшується швидкість проходу холо- 
дильного агенту крізь апарат. В результаті цього відповідно зменшується величина переохолодження холодильного агенту в конденсаторі (рис. 1).

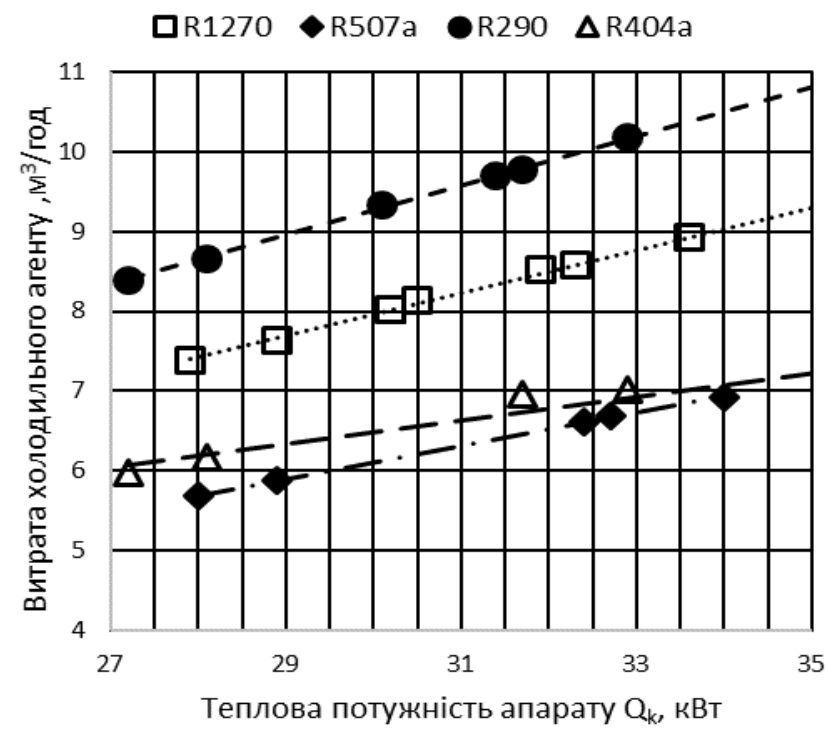

Рисунок 2 - Графік зміни об'ємної витрати холодильного агенту крізь апарат в залежності від теплової потужності теплообмінника

Енергетична ефективність теплообмінників 3 повітряним охолодженням можна охарактеризувати співвідношенням двох видів енергії: теплоти $Q_{k}$, яка передається через поверхню теплообміну, та роботи $N$, яка витрачається на подолання гідродинамічного опору апарату.

Енергетичний коефіцієнт визначався за формулою:

$$
E=Q_{k} / N \text {, }
$$

де $Q_{k}$ - теплова потужність конденсатора 3 повітряним охолодженням, Вт; $N$ - потужність електродвигуна вентилятора, Вт.

На рисунку 3 представлено графік зміни енергетичного коефіцієнту конденсаторів в залежності від питомої витрати енергії та заправленого холодильного агенту.

Питома витрата енергії в конденсаторі з повітряним охолодженням розраховувалася за формулою:

$$
N_{f}=N / F,
$$

де $F$ - площа теплообмінної поверхні, м² .

Енергетична ефективність теплообмінного апарату як окремого елементу холодильного контуру практично не залежить від типу холодильного агенту (рисунок 3 ). Основний термічний опір для конденсаторів холодильних установок $з$ повітряним охолодженням зосереджено на боці повітря. Однак, термодинамічні параметри холодильного агенту (температура на вході та виході, тиск конденсації і т. д.) при використанні певної конструкції конденсатора або схемного рішення вузла конденсації холодильного агенту (наприклад, встановлення в схему форконденсатора, переохолоджувача) впливають в результаті на термодинамічну ефективність холодильної установки в цілому.

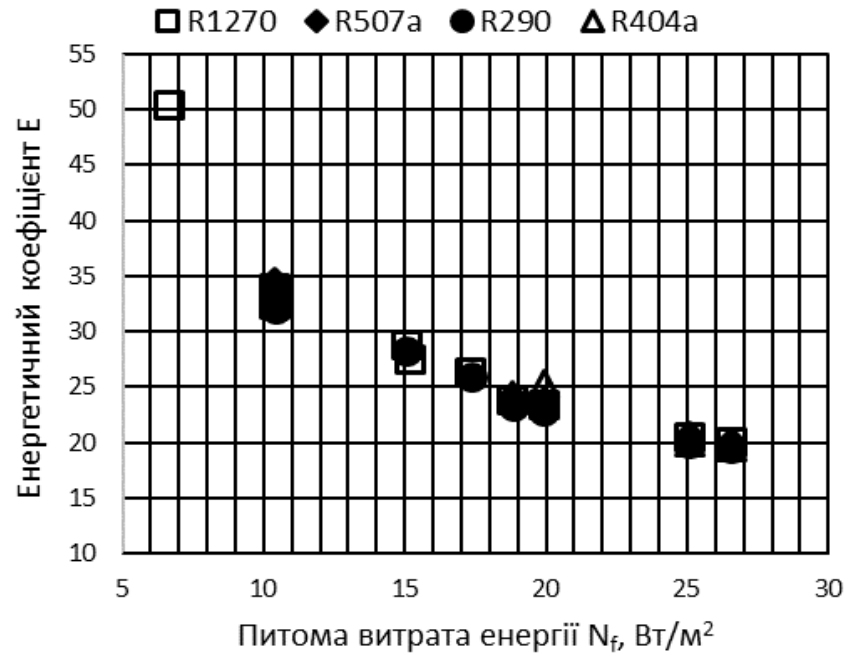

Рисунок 3 - Графік зміни енергетичного коефіцієнту конденсатору в залежності від питомої витрати енергії та заправленого холодильного агенту

На рисунку 4 представлено зіставлення конденсатору з повітряним охолодженням, роботу якого змодельовано при заправці різними холодильними агентами за умови однакової температури конденсації та параметpax зовнішнього повітря. На рис. 4 видно, що при переході на інший холодильний агент суттєво змінюється потужність апарату. Наприклад, якщо холодильну установку буде переведено 3 хладону R404a на R417a, потужність апарату зменшиться на 9,2\%.

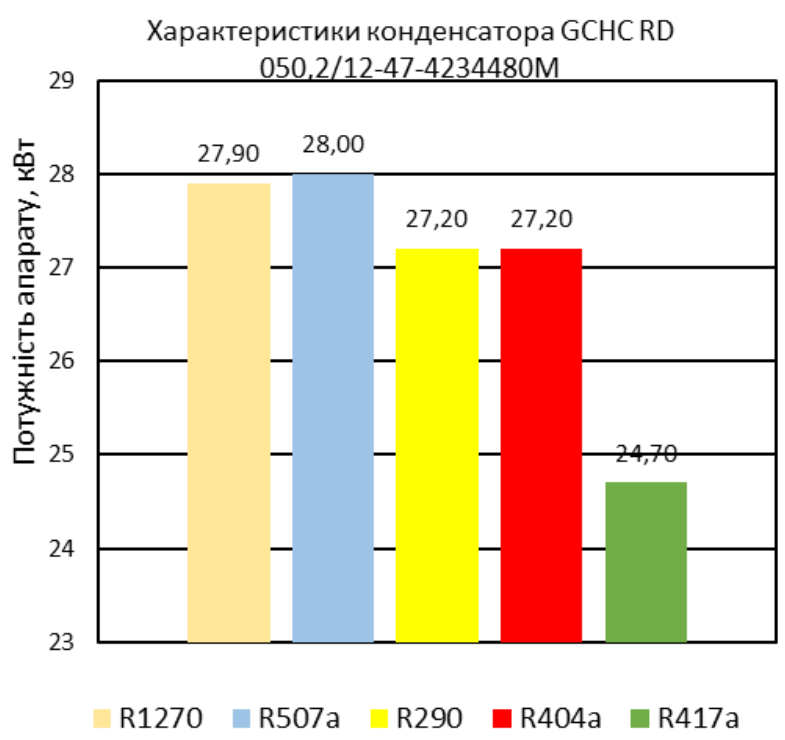

Рисунок 4 - Графік зміни потужності конденсатора в залежності від марки холодильного агенту (при незмінному тепловому навантаженні та параметрах навколишнього середовища)

У програмному комплексі фірми Гюнтнер було змодельовано режими роботи конденсатору 3 повітряним охолодженням GCHV RD 080.2MF/11A-55-0QX4.16B.M.

На рисунку 5 представлено графіки залежностей

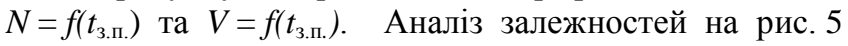
свідчить, що зростання температури зовнішнього пові- 
тря на вході в конденсатор при дотриманні незмінної температури конденсації призводить до збільшення необхідної потужності електродвигуна та збільшення витрати повітря крізь апарат. Збільшення витрати повітря досягається за рахунок підвищення швидкості обертання вентилятора та відповідно підвищення рівня шумових характеристик обладнання.

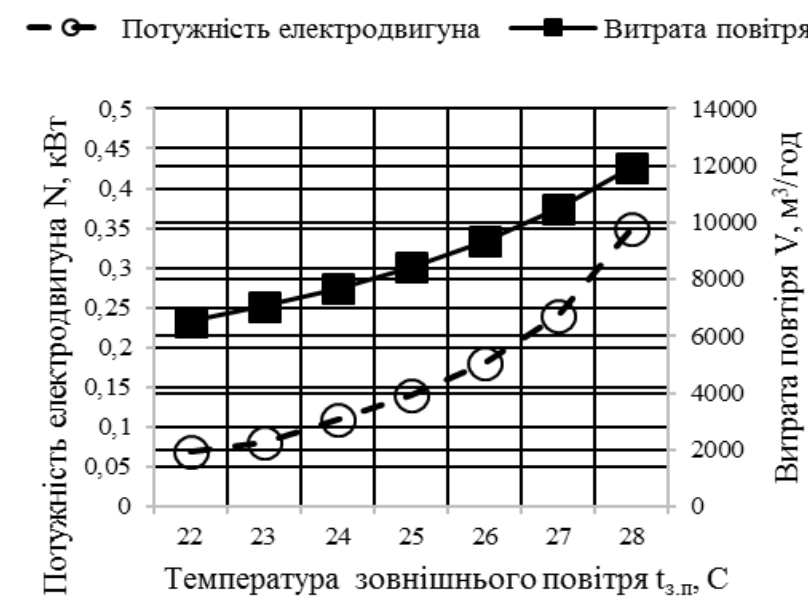

Рисунок 5 - Графік залежностей $N=f\left(t_{\text {з.п. }}\right)$ та $V=f\left(t_{3 . п .}\right)$

Підвищення температури зовнішнього повітря від $22{ }^{\circ} \mathrm{C}$ до $24{ }^{\circ} \mathrm{C}$ супроводжується збільшенням витрати повітря з 2000 до $4000 \mathrm{~m}^{3} /$ год з відповідним збільшенням енергоспоживання від 0,22 кВт до 0,35 кВт.

При перевищенні температури зовнішнього повітря $25^{\circ} \mathrm{C}$ для даної моделі конденсатору темпи зростання необхідної витрати повітря крізь апарат та відповідно необхідної потужності електродвигуна зростають дуже швидко (рис. 5).

На рисунку 6 представлено графік залежності $E=f\left(t_{3 . п .}\right)$. При зниженні температури повітря на вході в

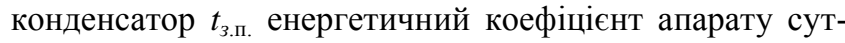
тєво зростає. Це пов'язано з підвищенням різниці температур між температурою поверхні теплообміну конденсатору і середньою температурою охолоджуючого потоку повітря.

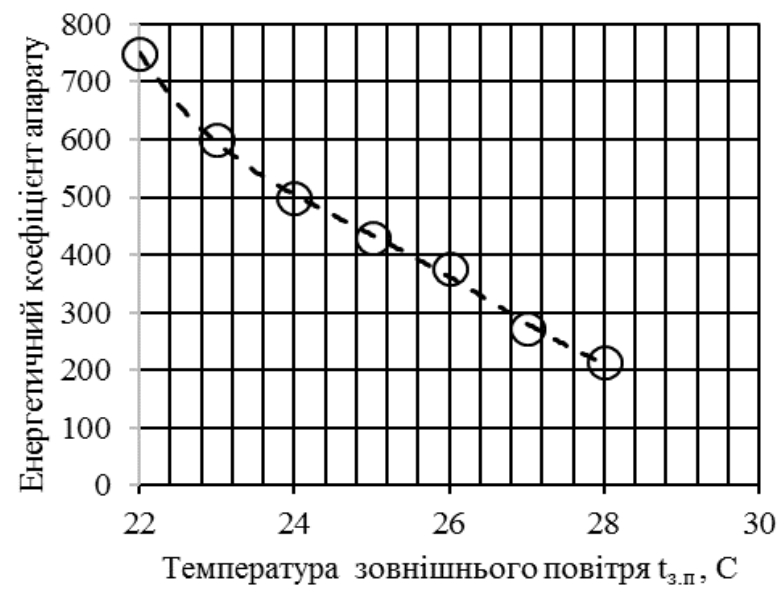

Рисунок 6 - Графік залежності $E=f\left(t_{\text {3.п. }}\right)$
Оптимальним виступає переведення роботи холодильної установки в нічний період часу або використання варіантів енергоресурсозбереження шляхом використання, наприклад, акумуляції холоду в нічний період.

Характерною особливістю проведених розрахунків $€$ той факт, що відсутність регулювання роботи вентиляторів конденсаторів шляхом зміни частоти обертання призводить до підвищеного енергоспоживання апарату навіть при експлуатації теплообмінника в умовах знижених температур навколишнього середовища.

\section{Висновки}

В статі проведено аналіз та дослідження роботи конденсаторів 3 повітряним охолодженням. Моделювання роботи конденсаторів повітряного охолодження шляхом використання програмного забезпечення фірми виробника теплообмінників дозволило виявити та розрахунковим шляхом підтвердити:

1. При переводі холодильної установки на інший холодильний агент суттєво змінюється потужність теплообмінного апарату. Наприклад, якщо холодильну установку буде переведено з хладону R404a на R417a, потужність апарату зменшиться на 9,2\%.

2. Зростання температури зовнішнього повітря на вході в конденсатор при дотриманні фіксованої температури конденсації та теплової потужності призводить до збільшення необхідної потужності електродвигуна та витрати повітря крізь апарат.

3. При зниженні температури повітря на вході в конденсатор енергетичний коефіцієнт апарату суттєво зростає. Це пов'язано з підвищенням різниці температур між температурою поверхні теплообміну конденсатору і середньою температурою охолоджуючого потоку повітря.

4. Оптимальним варіантом виступає перевід роботи холодильної установки в нічний період часу або використання варіантів енергоресурсозбереження шляхом використання, наприклад, акумуляції холоду в нічний період.

Стрімкий розвиток математичного моделювання фізичних процесів надає змогу у короткі строки проводити масштабні віртуальні експерименти 3 отриманням цікавих результатів для вивчення питання можливих шляхів підвищення енергоефективності теплообмінного обладнання. Великий інтерес викликає подальший аналіз тепло-аеродинамічних характеристик апаратів 3 повітряним охолодженням методом кінцево-елементного моделювання.

\section{Література}

1. Шавра В.М., Годин С.Р., Громоздин С.Н., Рогова В.А. Тенденция конструирования воздушных конденсаторов малых холодильных машин // Холодильная техника, 1982. - № 7. - С.54-58.

2. Несвицкий А.А., Кабаков А.Н., Максименко В.А. Выбор оптимальных режимов охлаждения конденсаторов холодильных установок // Холодильная техника1985. - №9. - С.39-43. 
3. Лагутін А.Ю., Стоянов П.Ф. Енергоефективні поверхні теплообміну апаратів повітряного охолодження: монографія // Одеса: Прес-кур'єр, 2018. - 216 с.

4. James Lawson Propst Air conditioner condenser optimization// THESIS Presented to The Faculty of the Division of Graduate Studies, Georgia, Institute of Technology, August, 1975, 144 p.

5. Chavan A.M., Deodas S.R. Investigation and optimization of air cooled condenser of chillers by replacing $\mathrm{Cu}$ to $\mathrm{Al}$ tubes//International Engineering Research Journal (IERJ) Special Issue 2, 2015, pp. 48734877

6. Aute V.C., Radermacher R. and Naduvath M.V. Constrained Multi-Objective Optimization of a Condenser Coil Using Evolutionary Algorithms// International Refrigeration and Air Conditioning conference, 2004

7. Stewart S.W., Aspelund K.A., Wright M.F., Shelton S.V. Residential Air Conditioner Finned-Tube Condenser Heat Exchanger Optimization // Southeastern Region Xi Technical conference April 6,2002.

8. Zahn W.R. Factors Influencing Automotive Air Conditioning Evaporator Optimization// SAE Paper No. 690131, January 13, 1969

9. Conklu O. Computer Simulation of Automotive AirConditioning Condensers// SAE Paper No. 720076, January 10, 1972.

10. Davis, G.L., Chianese F., Jr. and Scott T.C. Computer Simulation of Automotive Air Conditioning Components, System, and Vehicle // SAE Paper No. 720077, January 10, 1972.

11.Schoonman W. Aircooler Optimization Aided by Computer, Symposium on Air-Cooled Heat Exchangers// Published by ASME, 1964, pp. 86-102.

12. Kutscher C., Costenaro D. Assessment of Evaporative Cooling Enhancement Methods for Air-Cooled Geothermal Power Plants// Presented at the Geothermal Resources Council (GRC),Annual Meeting Reno, Nevada, September, (2002).

13. SaizJabarrdo, J.M., Mamani, W.G. Modelingand Experimental Evaluation of Parallel Flow MicroChannel Condensers// J.Braz., Soc., Mech., Sci and Eng., Vol.25, No.2, Reo de Janeiro, Apr./June, 2003.
14. Tarrad A.H., Shehhab U.S. The Prediction of Environment Effect on the Performance of a Vapour Compression Refrigeration System in Air Conditioning Application// Journal of Engineering and Development. Vol.11, No.1, March 2007, pp.169-189.

15. Tarrad A.H., Khudor, D.S., and Abdul Wahed, M. A Simplified Model for the Prediction of the Thermal Performance for Cross Flow Air Cooled Heat Exchangers with a New Air Side Thermal Correlation // Journal of Engineering and Development, Vol. 12, No.3, 2008.

16. Tarrad A.H., Saleh F.A., Abdulrasool, A.A. A Simplified Numerical Model for a Flat Continuous Triangle Fins Air Cooled Heat Exchanger Using a Step by Step Technique// Engineering and Development Journal, Vol. 13, No. 3, pp. 38-59, Al-Mustansiriya University, Baghdad, (2009).

17. Tarrad A.H. A Numerical Model for Performance Prediction of Dry Cooling Conditions of Air Cooled Condensers in Thermal Power Plant Stations// Journal of Engineering and Technology, Vol.28, No.16, Baghdad, Iraq, (2010).

18. Tarrad A.H. and Khudor, D.S. A Correlation for the Air Side Heat Transfer Coefficient Assessment in Continuous Flat Plate Finned Heat Exchangers// Transactions of the ASME, Journal of Thermal Science and Application, Vol. (7), No. 2, Paper No. TSEA-14-1194, DOI: 10.11151/1.4029459, 2015.

19. Якобсон В.Б. Малые холодильные машины. - М.: Пищевая промышленность, 1977. - 367 с.

20. Parikshit A. Ladke and C.S. Choudhari Design Optimization and Performance Analysis of Condenser for HVAC Automobile System for R-290// International Journal of Current Engineering and Technology (Available at http://inpressco.com/category/ijcet )

21.J.B. Copetti, M.H. Macagnan, C.O. Figueiredo Design and optimization of minichannel parallel flow condensers// Seventh Int. Conference on Enhanced, Compact and Ultra-Compact Heat Exchangers: From Microscale Phenomena to Industrial Applications, 2009.

Отримана в редакції 17.09.2018, прийнята до друку 04.12.2018

\title{
Analysis of the energy performance of air-cooled condensers
}

\author{
P. F. Stoianov \\ Odessa National Academy of Food Technologies, 112 Kanatnaya St., Odessa, 65039, Ukraine \\ $\triangle$ e-mail: palfomich@gmail.com
}

\begin{abstract}
Air-cooled condensers are widely used in modern refrigeration systems and are distinguished by high energy efficiency. Taking into account the continuous growth of the modern society needs of artificial cold, increasing the energy efficiency of air-cooled heat exchangers, improving their mass-size characteristics are up-to-date issues. This paper presents an overview of air-cooled heat exchangers for refrigeration systems and their optimizations with critical review. The objectives of an energy performance of air-cooled condensers for refrigeration system are identified and discussed, including optimal system operation, ability for continuous turndown, and fast response to changes in the operating conditions. The key directions of energy efficiency improving for air-cooled heat exchangers are presented. The air-cooled condensers performance is investigated for changing their regime parameters. The refrigeration system working fluid impact factor on the heat exchangers characteristics is estimated. The Air-cooled condenser performance is analyzed during refueling of the refrigeration system with different refrigerants: R1270, R507a, R290, R404a, R417a. If the refrigeration system is needed to retrofit refrigerant from $R 404$ a to $R 417$ a, the apparatus power will be reduced by $9.2 \%$. This fact requires considerable attention from design engineers during the reconstruction of the operating-and the design of new refrigeration systems as
\end{abstract}


well as energy systems. By calculation the dependence of the refrigerant overcooling degree from the specific consumption of cooling air for various refrigerants on the condenser output is determined. Air-cooled condensers have a great potential for improving energy efficiency when organizing energy efficient performance for ventilators. The author evaluates the dependence of the air flow loose through the heat exchanger, the change of the required fan power from the temperature of the cooling air at the apparatus input, subject to the fixed refrigerant condensation temperature and the heat capacity of condenser. As a result of the done analysis, it was found that when the outside temperature rises from $25^{\circ} \mathrm{C}$ to $28^{\circ} \mathrm{C}$, the energy consumption of the serial unit fan increases by $250 \%$. According to the serial heat exchange equipment simulation of its performance, the author is estimated the energy efficiency of air-cooled condensers depending on the environmental parameters, the charged refrigerants of the refrigeration system, the specific flow rate of cooling air per unit area of the heat-exchange surface and is developed recommendations for air-cooled heat exchangers performance optimizing.

Keywords: Modeling; Air-Cooled Condenser; Energy Performance; Heat Exchange; Heat Flux Density; Refrigerant Agent; Optimization.

\section{References}

1. Shavra, V.M., Godin, S.R., Gromozdin, S.N., Rogova, V.A. (1982) Tendentsiya konstruirovaniya vozdushnyih kondensatorov malyih holodilnyih mashin. Holodilnaya tehnika, 7,.54-58.

2. Nesvitskiy, A.A., Kabakov, A.N., Maksimenko, V.A. (1985) Vyibor optimalnyih rezhimov ohlazhdeniya kondensatorov holodilnyih ustanovok. Holodilnaya tehnika, 9, 39-43.

3. Lagutin, A.Yu., Stoyanov, P.F. (2018) Energoefektivni poverhni teploobminu aparativ povitryanogo oholodzhennya: monografiya. Odesa: Pres-kur'er, 216 p.

4. James Lawson Propst (1975) Air conditioner condenser optimization// THESIS Presented to The Faculty of the Division of Graduate Studies, Georgia, Institute of Technology, August, $144 \mathrm{p}$.

5. Chavan, A.M., Deodas, S.R. (2015) Investigation and optimization of air cooled condenser of chillers by replacing $\mathrm{Cu}$ to $\mathrm{Al}$ tubes. International Engineering Research Journal, Special Issue 2, 4873-4877.

6. Aute, V.C., Radermacher, R. and Naduvath, M.V. (2004) Constrained Multi-Objective Optimization of a Condenser Coil Using Evolutionary Algorithms. International Refrigeration and Air Conditioning conference, 2004

7. Stewart, S.W., Aspelund, K.A., Wright, M.F., Shelton, S.V. (2002) Residential Air Conditioner Finned-Tube Condenser Heat Exchanger Optimization. Southeastern Region Xi Technical conference April 6, 2002.

8. Zahn, W.R. (1969) Factors Influencing Automotive Air Conditioning Evaporator Optimization. SAE Paper No. 690131, January 13, 1969

9. Conklu O. (1972) Computer Simulation of Automotive Air-Conditioning Condensers. SAE Paper No. 720076, January 10, 1972.

10. Davis, G.L., Chianese, F. Jr., and Scott, T.C. (1972) Computer Simulation of Automotive Air Conditioning-Components, System, and Vehicle. SAE Paper No. 720077, January 10, 1972.

11. Schoonman, W. (1964) Aircooler Optimization Aided by Computer, Symposium on Air-Cooled Heat Exchangers. Published by ASME, 1964, pp. 86-102.

12. Kutscher, C., Costenaro, D. (2002) Assessment of Evaporative Cooling Enhancement Methods for Air-Cooled Geothermal Power Plants. Presented at the Geothermal
Resources Council (GRC),Annual Meeting Reno, Nevada, September, 2002.

13. SaizJabarrdo, J.M., Mamani,W.G. (2003) Modelingand Experimental Evaluation of Parallel Flow MicroChannel Condensers. J.Braz., Soc., Mech., Sci and Eng., vol. 25, iss. 2, Reo de Janeiro, Apr./June, 2003.

14. Tarrad A.H., Shehhab U.S. (2007) The Prediction of Environment Effect on the Performance of a Vapour Compression Refrigeration System in Air Conditioning Application. Journal of Engineering and Development, 11(1), 169-189.

15. Tarrad, A.H., Khudor, D.S., and Abdul Wahed M. (2008) A Simplified Model for the Prediction of the Thermal Performance for Cross Flow Air Cooled Heat Exchangers with a New Air Side Thermal Correlation. Journal of Engineering and Development, 12(3).

16. Tarrad, A.H., Saleh, F.A., Abdulrasool, A.A. (2009) A Simplified Numerical Model for a Flat Continuous Triangle Fins Air Cooled Heat Exchanger Using a Step by Step Technique. Engineering and Development Journal, 13(3), 38-59, Al-Mustansiriya University, Baghdad.

17. Tarrad, A.H. (2010) A Numerical Model for Performance Prediction of Dry Cooling Conditions of Air Cooled Condensers in Thermal Power Plant Stations. Journal of Engineering and Technology, 28(16), Baghdad, Iraq.

18. Tarrad, A.H., Khudor, D.S. (2015) A Correlation for the Air Side Heat Transfer Coefficient Assessment in Continuous Flat Plate Finned Heat Exchangers. Transactions of the ASME, Journal of Thermal Science and Application, 7(2), Paper No. TSEA-14-1194. DOI: 10.11151/1.4029459

19. Yakobson V.B. Malyie holodilnyie mashinyi. - M.: Pischevaya promyishlennost, 1977. - $367 \mathrm{~s}$.

20. Parikshit A. Ladke and Choudhari C.S. Design Optimization and Performance Analysis of Condenser for HVAC Automobile System for R-290. International Journal of Current Engineering and Technology. Available at http://inpressco.com/category/ijcet

21. Copetti, J.B., Macagnan, M.H., Figueiredo, C.O. (2009) Design and optimization of minichannel parallel flow condensers. Seventh International Conference on Enhanced, Compact and Ultra-Compact Heat Exchangers: From Microscale Phenomena to Industrial Applications, 2009

Received 17 September 2018 Approved 04 December 2018 Available in Internet 30 December 2018 